RISTO HONKONEN (toim. 2002) Koulutuksen lumo - Retoriikka, politiikka ja arviointi Tampere University Press

Koulutuksen lumo -teos on Reijo Raivolan kunniaksi toimitet- tu juhlakirja hänen jäädessä eläkkeelle Tampereen yliopiston kasvatustieteen professorin virasta. Mielelläni yhdyn niiden joukkoon, jotka onnittelevat häntä näyttävästä urasta ja toivottavat hänelle mukavia eme- ritusprofessorin vuosia.

Juhlakirjoja ei nykyään enää toimiteta siinä määrin kuin takavuosina. Syitä lienee moniakin, yksi ehkä se, ettei tämäntyyppisissä teoksissa julkaistuja artikkeleita noteerata tieteellisinä 
meriitteinä samalla tavoin kuin aiemmin. Jotenkin on vaikeaa sijoittaa tällaista julkaisua tämän päivän tieteellisten tuotosten joukkoon. Tarkastelenkin teosta nimenomaan juhlakirjana. Sellaisena se on mielestäni onnistunut tuntien Raivolan intressit tutkijana ja koulutuspolitiikan taustavaikuttajana.

Teos jakautuu neljään osaan: koulutusretoriikka, koulutuspolitiikka, koulutuksen arviointi ja koulutus kansainvälisessä katsannossa. Käsittääkseni Raivolan ominta aluetta ovat olleet koulutuspolitiikka ja koulutuksen arviointi, mutta myös vertailevan kasvatustieteen alueella hänellä on näyttöjä. Retoriikkaahan löytyy kaikkiin noihin kolmeen alueeseen liittyen.

Kun sain teoksen käsiini, ensimmäiseksi silmäilin, missä määrin juhlakirjan artikkeleiden kirjoittajat olivat 'kumartaneet juhlakalua' eli tehneet viittauksia Raivolan julkaisuihin. Useinhan juhlakirjoista näkyy, että hyvin tarkoitushakuisesti on lainattu juhlimisen kohdetta. Tästä teoksesta voidaan todeta, että itse asiassa juhlinnan kohteeseen tehtyjä viittauksia on yllättävänkin vähän. Eniten huomiota näyttää saaneen Raivolan kirja Tehoa vai laatua koulutukseen vuodelta 2000.

\section{MITÄ RETORIIKAN TAKANA?}

Itseäni kosketti teosten osista ehkä eniten koulutusretoriikkaa koskeva osa ja sen artikkelit. Varsinkin Jukka Tuomiston artikkeli 'Elinikäisen oppimisen retoriikka ja vallankäyttö' ja Risto Honkosen artikkeli 'Työssä oppimisen retoriikat' saivat minut pohtimaan omaa suhtautumistani kyseisiin käsitteisiin ja niiden taustalla oleviin ajatuksiin. Useimmille meistä on tuttua elinikäisen oppimisen käsitteen ja sen eri versioiden jatkuva lanseeraaminen aina 1950-luvulta lähtien. UNESCO, OECD, Council of Europe ja viime aikoina EU ovat pyrkineet vahvistamaan uskoamme elinikäisen oppimisen välttämättömyyteen, jopa pakkoon. Harvemmin on voitu lukea kirjoituksia, joissa olisi todella kriittisesti kyseenalaistettu tämä ideologia tai kysytty, onko jatkuva oppiminen niin iloinen asia, kuin vuonna 1997 ilmestynyt 'Oppimisen ilo'-mietintö jo otsikossaan julistaa. Kuten Tuomisto artikkelissaan toteaa, retoriikan merkitys on jälleen korostumassa. Sen avulla taitavat demagogit suostuttelevat oman näkemyksensä taakse niitäkin kansalaisryhmiä tai ihmisiä, jotka suhtautuvat epäillen heidän ja muiden vallanpitäjien ajatuksiin ja uudistusvaatimuksiin. Tulee mieleeni kysyä, missä määrin myös yliopisto-opetuksessa harjoitetaan samanlaista kritiikitöntä demagogiaa levitettäessä ilosanomaa elinikäisestä oppimisesta? Yhdyn Tuomiston ehdotukseen, että tarvitaan keskustelua siitä, mihin kukin elinikäisen oppimisen diskurssilla oikein pyrkii, kuka suostuttelee ketä ja millä keinoin.

Keskustelu työssä oppimisen merkityksestä käynnistyi käsittääkseni 1980-luvun lopulla ja koko 90-luvun ajan enenevässä määrin keskusteltiin ja yritettiin tutkia sitä, mikä on formaalin ja informaalin oppimisen keskinäinen suhde esimerkiksi ammattitaidon omaksumisessa ja sen kehittämisessä. Kuten Honkonen toteaa artikkelissaan, suomalaisessakin koulutuspolitiikassa työssä oppimi- nen, tai työssäoppiminen, on nostettu erityisesti ammatillisen oppimisen paradigmaksi.

\section{TYÖSSÄOPPIMISEN RETORIIKKASTA}

Honkonen pyrkii osoittamaan, että työssäoppimispuhe on teknologisen funktionalismin läpitunkemaa eikä puhe ole mitenkään neutraalia kuvausta työstä ja oppimisesta, vaan tietyn historiallisen ajanjakson yhteiskuntaideologian sävyttämää. Kansainvälisessä kirjoittelussa aktiivisimpia informaalin oppimisen puolestapuhujia ovat olleet amerikkalaiset Victoria Marsick ja Karen Watkins, joiden ajatuksia itsekin tunnustan opetuksessani välittäneeni opiskelijoilleni - usein sellaisenaan. Merkittävimpiä informaalin oppimisen kyseenalaistajia oli vuonna 1998 ilmestynyt J. Garrickin teos Informal Learning in the Work-place. Unmasking Human Re-source Development -teos, johon Honkonenkin viittaa.

Honkonen liittää työssäoppimisen retoriikkaan $\mathrm{mm}$. kokemuksellisen oppimisen ja oppivan organisaation käsitteet, joita niitäkin viljellään usein turhan kritiikittömästi. Mielestäni Honkonen osuu oikeaan, kun hän artikkelinsa lopulla toteaa:

”Työssä oppiminen nojaa tekniseen funktionalismiin jopa vahvemmin kuin kouluoppiminen, sillä edellisessähän juuri pyritään tuottamaan välittömästi työssä hyödynnettäviä taitoja, kun muodollisessa koulutuksessa pyritään yleensä myös muihin tavoitteisiin, kuten yleisen ja siirrettävän avainosaamisen hankkimiseen, kriittisyyteen, kansalaisuu- 
den valmiuksien oppimiseen, oppimaan oppimiseen ja luovuuteen."

\section{KOULUTUSPOLITIIKKAA}

Teoksen toiseen, koulutuspolitiikkaa käsittelevään osaan on myös saatu kiintoisia artikkeleita. Risto Rinne kysyy artikkelissaan, onko loppu näkyvissä kansalliselle koulutuspolitiikalle globalisaation, tai kuten hän sanoo - pallottumisen - seurauksena? Keskeiseksi kysymykseksi näyttää Rinteen artikkelissa muodostuvan niin- sanottujen uusliberalististen aaltojen vaikutus koulutusta koskevaan päätöksentekoon kansallisella tasolla. Rinne ei anna selkeää vastausta siihen, loppuuko kansallinen koulutuspolitiikka, mutta koulutuspolitiikassamme ilmenneiden muutosten alkuperäksi hän väittää kansainvälisissä koulutusideologioiden trendit enemmän kuin kansalliset poliittiset pyrkimykset. Koulutuspoliittisesta keskustelusta kiinnostunut lukija saa paljon ajatuksia Rinteen artikkelista ja hyviä vinkkejä lähdeluettelosta.

Ulrich Teichlerin artikkeli korkeakoulutuksen monimuotoistumisesta ja yksittäisen korkeakoulun profiilista on todella ajankohtainen suomalaistenkin yliopistojen ja korkeakoulujen etsiessä omia profiilejaan ja vahvuusalueitaan ja pohdittaessa kaksiportaisen tutkintojärjestelmän vaikutuksia koulutusohjelmiin. Valitettavasti vain Teichlerin artikkeli on jäänyt turhan lyhyeksi, jotta siitä saisi kunnon eväitä suomalaiseen korkeakoulupoliittiseen keskusteluun. Pekka Ruohotien artikkeli 'Oppiminen tavoitteena' tuntuu jotenkin väärään koh- taan sijoittuneelta, siksi vähän artikkeli sisältää koulutuspoliittista ainesta painopisteen ollessa varsin tuttujen oppimiskäsitysten esittelyssä.

\section{OPETUKSEN LAADUSTA}

Kolmas osa teosta käsittelee koulutuksen arviointia ja osa alkaa lupaavasti tunnetun ruotsalaisen kasvatustieteilijän Ulf P. Lundgrenin artikkelilla 'Voidaanko koulujärjestelmää arvioida kansallisella tasolla?' Tapausesimerkkinä koulujärjestelmien kansallisesta arvioinnista Lundgren esittelee ruotsalaista, vahvasti komiteatyöskentelyyn nojautunutta koulujärjestelmän arviointi- ja kehittämistoimintaa. Naapurimaan toimia seuranneille tämä esittely ei tuo uutta, mutta asiaa tuntemattomille se on hyvä tiivistys. Itse odotin artikkelilta enemmän arvioinnin teoreettis-metodologista tarkastelua. Lundgren näyttää valinneen helpomman tien pitäytymällä poliittis-hallinnollisessa arvioinnin tarkastelussa.

Viime vuosina yleistyneet opetuksen laatupalkinnot ovat pakottaneet suomalaiset yliopistot lopultakin kiinnittämään huomion tutkimuksen ohella yliopistoissa annettavan opetuksen laatuun ja tasoon. Myös virantäytöissä on alettu jonkin verran ottamaan huomioon opetusansioita tutkimusmeriittien ohella. Toisin sanoen ulkoiset sanktiot ovat vuosikymmeniä kestäneiden puheiden jälkeen johtaneet siihen, että yliopistoissa annettavaa opetusta ja opettajien opetustaitoa on alettua arvioida ja kehittää. Matti Parjasen artikkeli 'Onnistuuko amerikkalainen takaisinsyöttö suomalaisessa yliopistossa?' on tässä mielessä ajan- kohtainen katsaus opiskelijapalautteiden merkitykseen opetuksen ja oppimisen kehittämistyössä. Parjanen esittelee erään amerikkalaisen opiskelijapalautejärjestelmän kokeilun tuloksia Tampereen yliopistossa. Vaikka tuon mallin käyttö sai osakseen kritiikkiäkin, Parjasen päätelmän mukaan palautemalleilla olisi käyttöä suomalaisissakin yliopistoissa. - Lisää amerikkalaisesta laadunvarmistuksesta tuo Stephen S. Winterin artikkeli 'Testaaminen ja laadun käsite Yhdysvaltain koulutuksessa'. Tosin tässä lyhyehkössä esittelyssä painopiste on lähinnä toisen asteen koulutuksen arvioinnissa.

Arviointijakson viimeisessä artikkelissa kokenut opetushallinnon virkamies Reijo Laukkanen tarkastelee evaluaatiota hallinnan 'suurena' lupauksena. Laukkasen kirjoitus on kiinnostava, onhan suomalaisessa opetushallinnossa viimeisen kymmenen vuoden aikana pyritty nostamaan arviointi keskeiseen asemaan hallinnossa jopa organisatorisin ratkaisuin. Laukkasen mukaan tänä päivänä evaluaatio otetaan koulutoimen eri asteilla vakavasti. Toisaalta hän nostaa varoittavan sormen pystyyn toteamalla, ettei kaikkea päätöksentekoa voi eikä pidä perustella evaluaatiolla. Evaluaatio voi parhaimmillaan tuoda tosiasioita, näkökulmia ja haastaa sisällölliseen keskusteluun. Huonoimmillaan se johtaa asioiden hallinnolliseen tarkasteluun, kuten Laukkanen artikkelinsa lopussa toteaa.

VERTAILEVAA KASVATUSTIEDETTÄ

Viimeisessä teoksen osassa koulutusta tarkastellaan kan- 
sainvälisessä katsannossa ja tämän jakson artikkeleissa onkin vahva vertailevan kasvatustieteen näkökulma. Jürgen Schriewer osoittaa mielenkiintoisella tavalla vertailevan kasvatustieteen näkökulmien ja lähestymistapojen muutokset historiallisessa perspektiivissä. Artikkeli on lukijan kannalta ehkä koko teoksen vaativin teoreettis-metodologisesti monitasoisessa tarkastelussaan. Artikkeliin liittyy tavanomaista laajempi lähteistö, joten vertailevasta kasvatustieteestä kiinnostuneelle Schriewerillä on paljon annettavaa. Muita tämän osan artikkeleita voidaan pitää tavanomaisempaa vertai- levaa kasvatustiedettä edustavina, voisiko sanoa Schriewerin teoreettisen taustaosan empiirisinä sovelluksina.

Risto Honkosen toimittama juhlakirja sisältää kaikkiaan kaksikymmentä artikkelia. Olen nostanut esiin vain niistä osan, nekin lähinnä oman mielenkiintoni perusteella. Joku muu lukija katsoisi varmasti muita artikkeleita esittelyn arvoisiksi.

Teoksen hyviä puolia on sen monipuolisuus. Siinä liikutaan koulutustoiminnan keskeisillä alueilla luoden mukavaa raamitusta kaikkein keskeisimmille toiminnoille - opetukselle ja oppimiselle. Teos olisi voinut olla hieman suppeampi eli muuta- man artikkelin toimitus olisi voinut jättää pois ja näin kirjan sisällöstä olisi tullut tasapainoisempi ja luettavampi. Varsinaiseksi tenttikirjaksi en teosta ottaisi. Sen sijaan käyttäisin sitä kasvatustieteen syventävien opintojen teemaseminaareissa yhtenä keskustelujen virittäjänä.

\section{Tapio Vaherva}

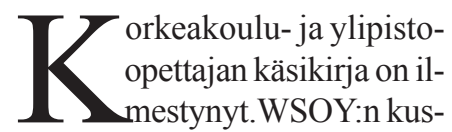
tantaman teoksen ovat toimittaneet Sari Ylänne-Lindblom ja Anne Negro Helsingin yliopiston kasvatustieteen laitokselta. Teos julkistettiin 10.2. 